\title{
Study on Operating Characteristics of Power Plant with Dry and Wet Cooling Systems
}

\author{
Tao Tang ${ }^{1}$, Jian-qun $\mathrm{Xu}^{{ }^{*}}$, Sheng-xiang $\mathrm{Jin}^{2}$, Hong-qi Wei ${ }^{1}$ \\ ${ }^{1}$ School of Energy and Environment, Southeast University, Nanjing, China \\ ${ }^{2}$ Beijing Energy Company Limited, Beijing, China \\ Email: tangtao_1026@163.com, ${ }^{*}$ qlj1062@163.com
}

Received February, 2013

\begin{abstract}
The represent paper will study the performance of the power plant with the combination of dry and wet cooling systems in different operating conditions. A thermodynamic performance analysis of the steam cycle system was performed by means of a program code dedicated to power plant modeling in design operating condition. Then the off-design behavior was studied by varying not only the ambient temperature and relative humidity but also several parameters connected to the cooling performance, like the exhaust steam flow rate, the air cooling fan load and the number of operating cooling water pumps and cooling towers. The result is an optimum set of variables allowing the dry and wet cooling system be regulated in such a way that the maximum power is achieved and low water consumption.
\end{abstract}

Keywords: Dry and Wet Condenser; Cooling Tower; Off-design; Characteristic Curve; Operational Optimization

\section{Introduction}

There are three ways of thermal power plants' cooling systems: dry cooling system, wet cooling system, and dry and wet cooling system. In China, the wet cooling system use in the power plans commonly, but in the northwest and northeast China where the water is shortage use air cooling system. The wet cooling systems have high thermal economy, but with high water consumption. The air cooling systems can save a lot of water, but the exhaust steam pressure is high and varying all the time for the impact of ambient temperature [1]. The wet and dry cooling systems combines the both advantages, it not only make full power when the ambient temperature is high but also with low water consumption $[2,3]$.

The present study was inspired by the operation of a power plant with the combined wet and dry cooling system (Figure 1), placed in Northwest China. The wet and dry cooling system is composed of an air cooled condenser in parallel with a water cooled condenser. In the wet cooling system, the cooling water which shared by two 300 MW Units, taken from the condenser passes through four wet mechanical draft cooling towers and returns to the condenser by two cooling water pumps.

The off-design performance of an air cooling condenser or water cooling condenser separately is well deeply investigated [4-6], but the study on the performance of complies wet and dry cooling system is rarely find. So the critical element of this study is the wet mechanical draft tower. The heat transfer in cooling tower is a very complex phenomenon. But it could be described by several equations [7-9] with some simplifying assumptions.

The purpose of the present paper is to explore the impact of a dry and wet cooling system on the thermo-dynamic performance of a power plant. This paper offers an original contribution for cooling system performance analysis by considering the dry and wet system together.

\section{Mathematical Model of Direct Air Cooling System}

\subsection{The Pressure of Air Condenser}

Using $\eta$-NTU method to calculate the condensate temperature of air condenser [1]:

$$
t_{s 1}=\frac{D_{c}\left(h_{c}-h_{c}^{\prime}\right)}{S_{y f} v_{y f} \rho_{a} c_{p}} \frac{1}{1-e^{-N T U}}+t_{a 1}
$$

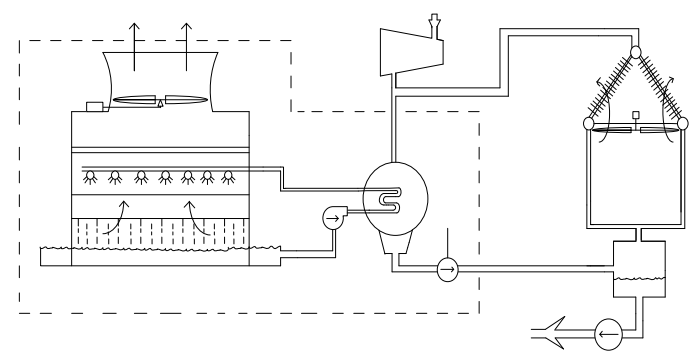

Figure 1. Schematic of the wet and dry cooling systems. 


$$
N T U=\frac{K S}{1000 S_{y f} v_{y f} \rho_{a} c_{p}}
$$

where: $D_{c}$ is exhaust steam flow rate. $h_{c}$ is condensate enthalpy. $h_{c}$ is exhaust steam enthalpy. $t_{a l}$ is ambient temperature. $c_{p}$ is air specific heat. $S_{y}$ is frontal area. $v_{y f}$ is face velocity. $\rho_{a}$ is air density. $N T U$ is heat transfer units. $K$ is heat transfer coefficient. $S$ is total area.

Using Equation (3) to calculate the condenser pressure of air condenser:

$$
p_{s 1}=9.81 \times\left(\frac{t_{s 1}+100}{57.66}\right)^{7.46}
$$

Exhaust steam pressure is:

$$
p_{c}=p_{s 1}+\Delta p_{1}
$$

where: $\Delta p_{1}$ is air condenser pressure drop.

\subsection{Air Cooling Condenser Heat transfer Coefficient}

The total heat transfer resistance including internal thermal resistance, external thermal resistance, and wall thermal resistance:

$$
\begin{gathered}
\frac{1}{K S}=\left(\frac{1}{\alpha_{i}}+\varepsilon_{i}\right) \frac{1}{S_{i}}+\frac{\delta_{b}}{\lambda_{b}} \frac{1}{S_{m}}+\left(\frac{1}{\alpha_{0}}+\varepsilon_{0}\right) \frac{1}{\eta_{0} S_{\text {wai }}} \\
S_{m}=\left(S_{0}-S_{i}\right) / \ln \left(S_{0} / S_{i}\right) \\
\eta_{0}=\left(S_{0}+\eta_{f} S_{c h i}\right) / S_{w a i}
\end{gathered}
$$

where: $K$ is total heat transfer coefficient. $S$ is total area. $\alpha_{i}$ and $\alpha_{0}$ are internal and external tube convective heat transfer coefficient. $\varepsilon_{i}$ and $\varepsilon_{0}$ are internal and external tube fouling resistance. $\delta_{b}$ is base pipe wall thickness. $\lambda_{b}$ is base pipe wall thermal conductivity. $S_{i}$ and $S_{0}$ are internal and external surface area of tubes. $S_{m}$ is the number heat transfer area of the base pipe. $S_{c h i}$ is fin surface area. $S_{w a i}$ is outer heat transfer area. $\eta_{f}$ is fin efficiency. $\eta_{0}$ is the total tube fin efficiency.

\section{Mathematical Model of Water Cooling System}

\subsection{The Pressure of Water Condenser}

Water condenser temperature could be got by Equation (8):

$$
t_{s 2}=t_{w 1}+\frac{h_{c}-h_{c}^{\prime}}{4.187 m}\left[1+\frac{1}{e^{\frac{A K}{4187 D w}}-1}\right]
$$

where $m=D_{w} / D_{c}$ is circulation ratio. $D_{c}$ is steam flow rate. $D_{w}$ is cooling water flow rate. $h_{c}-h_{c}$ ' is $1 \mathrm{~kg}$ steam's latent heat. $t_{w l}$ is cooling water temperature to condenser. $K$ is heat transfer coefficient. $A$ is cooling area.

Then the water condenser pressure $p_{s 2}$ can be calcu- lated by Equation (3), the exhaust steam pressure is:

$$
p_{c}=p_{s 2}+\Delta p_{2}
$$

where: $\Delta p_{2}$ is water condenser pressure drop.

\subsection{Cooling Water Temperature to Water Condenser}

In a closed-loop cooling water system, cooling water temperature to condenser equals cooling water temperature from cooling tower, it is not only affected by environmental conditions, but also by the design parameters and operating conditions of the cooling tower.

At present, the cooling tower thermodynamic calculation use enthalpy method commonly $[7,8]$. The equations are not shown in this paper.

\section{Results and Discussion}

The power plant with dry and wet cooling systems can operate as three cases: direct air cooling (Dry), dry and wet cooling system with one cooling water pump and two wet mechanical draft towers $\left(D \& W_{1}\right)$, and dry and wet cooling system with two cooling water pumps and four wet mechanical draft towers $\left(\mathrm{D} \& \mathrm{~W}_{2}\right)$. Assuming two Units at the same operating conditions, each Unit can get half of the circulating cooling water flow rate.

In order to optimize the operation, it must study the respective operating conditions off-design characteristics fistly.

\subsection{Design Parameters}

Table 1 shows the main design parameters of the Unit with wet and dry cooling systems.

Each considered variable is subjected to the constraints listed in Table 2, it contains any possible the power plant operating condition during the year.

Table 1. Design parameters.

\begin{tabular}{lcc}
\hline \multicolumn{1}{c}{ Name } & Unit & Content \\
\hline Ambient temperature & ${ }^{\circ} \mathrm{C}$ & 23.6 \\
Atmospheric pressure & $\mathrm{kPa}$ & 90.06 \\
Relative humidity & $\%$ & 86.84 \\
Gross power output & $\mathrm{MW}$ & 300 \\
Exhaust steam flow rate & $\mathrm{t} / \mathrm{h}$ & 614.23 \\
Exhaust steam enthalpy & $\mathrm{KJ} / \mathrm{kg}$ & 2437.9 \\
Exhaust steam pressure & $\mathrm{kPa}$ & 15 \\
AC cooling area & $\mathrm{m}^{2}$ & 492810 \\
AC frontal area & $\mathrm{m}^{2}$ & 5128 \\
AC face velocity & $\mathrm{m} / \mathrm{s}$ & 2.91 \\
Wet condenser cooling area & $\mathrm{m}^{2}$ & 3700 \\
Cooling water flow rate & $\mathrm{t} / \mathrm{h}$ & 12100 \\
Gas-water ratio & $/$ & 0.506 \\
CT cooling number & $/$ & 1.12 \\
\hline
\end{tabular}




\subsection{Dry configuration}

The exhaust steam flow rate and ambient temperature influence on exhaust pressure can be got by using mathematical model of direct air cooling systems mentioned before. Figures 2-5 reports some of the parametric analysis results for the Dry configuration. As can be seen from these Figs, the exhaust pressure rise with exhaust steam flow rate increases and ambient temperature rises. And the higher the ambient temperature, this trend is more obvious. The exhaust pressure will drop when AC fan load increases. The AC fan load should be operated according to the maximum load to get the highest power production, because auxiliary power consumption will rise as $\mathrm{AC}$ fan load rising.

Table 2. Parametric analysis ranges.

\begin{tabular}{lcc}
\hline \multicolumn{1}{c}{ Input variables } & Unit & Ranges \\
\hline Ambient temperature & ${ }^{\circ} \mathrm{C}$ & $-20-35$ \\
Relative humidity & $\%$ & $20-100$ \\
Air condenser fan load & $\%$ & $10-100$ \\
Exhaust steam flow rate & $\mathrm{t} / \mathrm{h}$ & $250-650$ \\
\hline
\end{tabular}

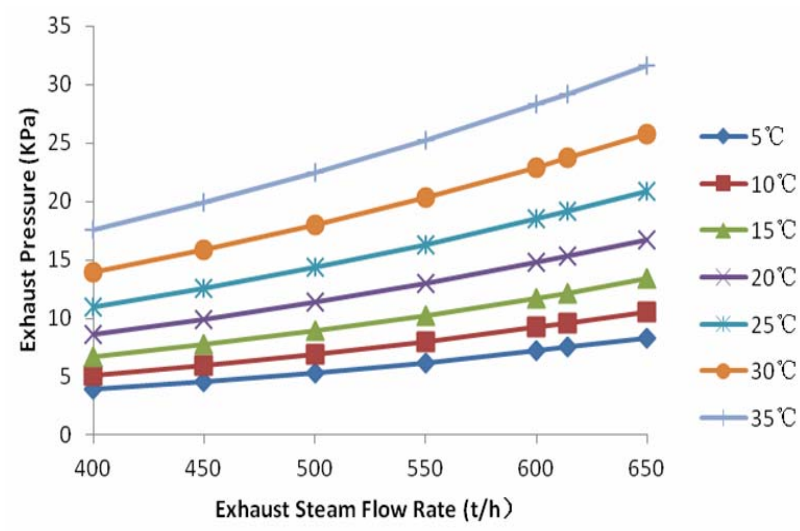

Figure 2. Exhaust steam flow rate and ambient temperature influence on exhaust pressure (AC fan load 100\%)-Dry.

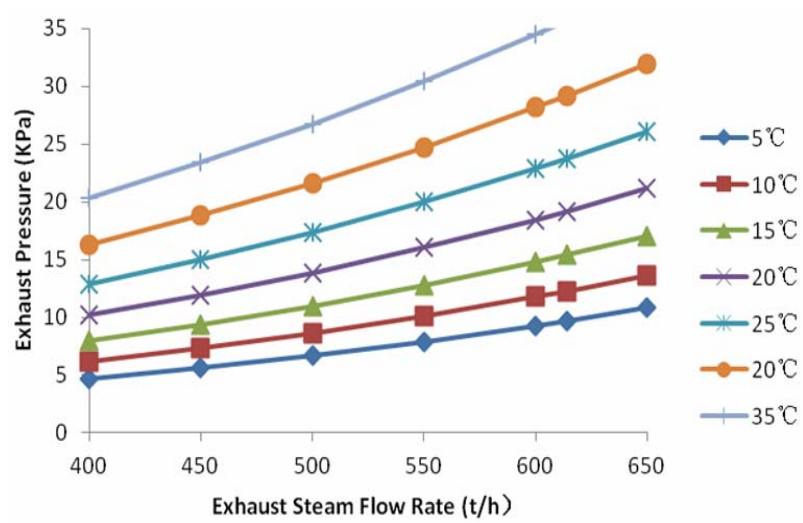

Figure 3. Exhaust steam flow rate and ambient temperature influence on exhaust pressure (AC fan load 75\%)-Dry.

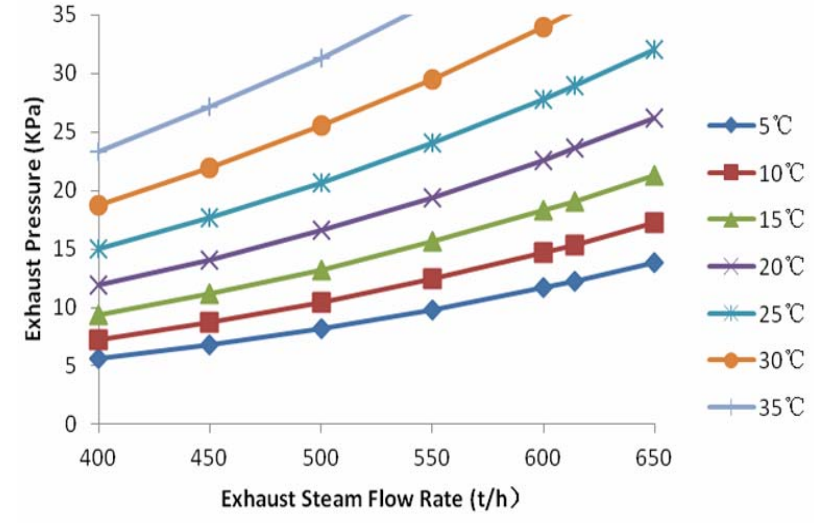

Figure 4. Exhaust steam flow rate and ambient temperature influence on exhaust pressure (AC fan load 50\%)-Dry.

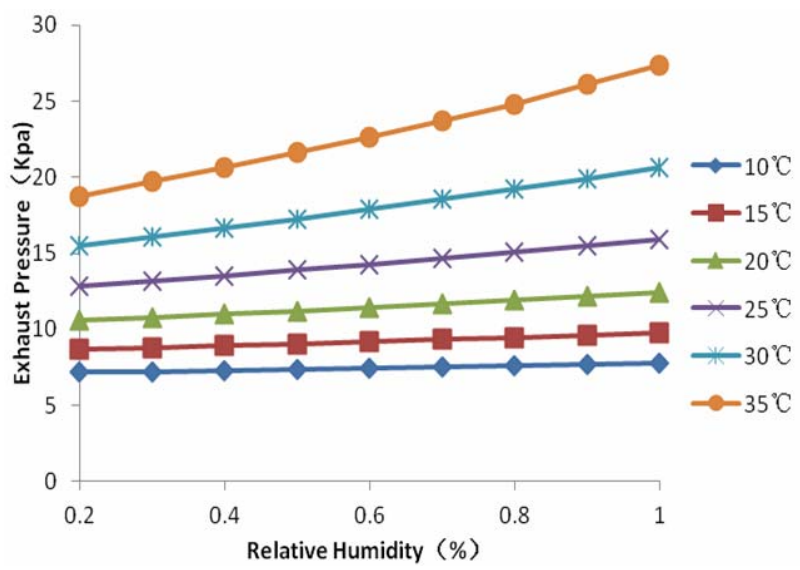

Figure 5. Relative humidity and ambient temperature influence on exhaust pressure-W\&D.

\subsection{W \& D Configuration}

The wet and dry cooling system off-design process was carried out by excel VBA code by using the mathematical model mentioned before.

Table 3 compares the model results against experimental date in three cases. The three cases show three different environmental conditions and power output. For all the cases, a good agreement was found between model results and experimental date: the maximum difference is lower than $5 \%$.

Figures 5-10 show the influence of the parameters mentioned before on exhaust pressure and dry proportion from W\&D model.

Figure 5 shows the exhaust pressure variation versus ambient temperature and relative humidity. As expected, exhaust pressure increases with rising relative humidity. The effect becomes more and more appreciable with increasing temperature. In the same range of ambient temperature changes, the greater the relative humidity the more obvious exhaust pressure changes. This is consistent with the dry proportion behabious shown in Figure 6: 
it is obvious that the steam flow rate entering the $\mathrm{AC}$ increases with raise in relative humidity. Relative humidity increases, the heat transfer capacity of the cooling tower decline, so wet proportion decreases.

The influence of the AC fan load on the cycle per- formance is shown in Figures 7-8. Obviously, the exhaust pressure decreases with rising $\mathrm{AC}$ fan load. The effect becomes more and more appreciable with increasing temperature. The steam flow rate entering the $\mathrm{AC}$ increases with raise in $\mathrm{AC}$ fan load.

Table 3. Comparison between model result (M) and experimental date (EXP).

\begin{tabular}{|c|c|c|c|c|c|c|c|c|c|}
\hline & \multicolumn{3}{|c|}{ Case 1} & \multicolumn{3}{|c|}{ Case 2} & \multicolumn{3}{|c|}{ Case 3} \\
\hline & M & EXP & Error & M & EXP & Error & M & EXP & Error \\
\hline Ambient temperature $\left({ }^{\circ} \mathrm{C}\right)$ & 22 & 22 & - & 30 & 30 & - & 26 & 26 & - \\
\hline Relative humidity (\%) & 68 & 68 & - & 48.3 & 48.3 & - & 74.5 & 74.5 & - \\
\hline Power output (MW) & 300 & 300.008 & - & 265 & 265.102 & - & 197 & 196.8 & - \\
\hline Exhaust steam flow rate $(\mathrm{t} / \mathrm{h})$ & 614.23 & - & - & 540 & - & - & 397.5 & - & - \\
\hline steam flow rate to wet $(\mathrm{t} / \mathrm{h})$ & 273.216 & 274.969 & $0.64 \%$ & 255.11 & 258.594 & $1.37 \%$ & 190.75 & 185.258 & $2.88 \%$ \\
\hline Air condenser fan load (\%) & 93 & 93 & - & 93 & 93 & - & 94 & 94 & - \\
\hline Cooling water temperature from $\mathrm{CT}\left({ }^{\circ} \mathrm{C}\right)$ & 29.287 & 29.768 & $1.64 \%$ & 34.3 & 34.271 & $0.08 \%$ & 30.85 & 31.536 & $2.22 \%$ \\
\hline Exhaust steam Pressure KPa & 14.707 & 14.717 & $0.07 \%$ & 17.364 & 17.371 & $0.04 \%$ & 10.73 & 11.058 & $3.06 \%$ \\
\hline
\end{tabular}

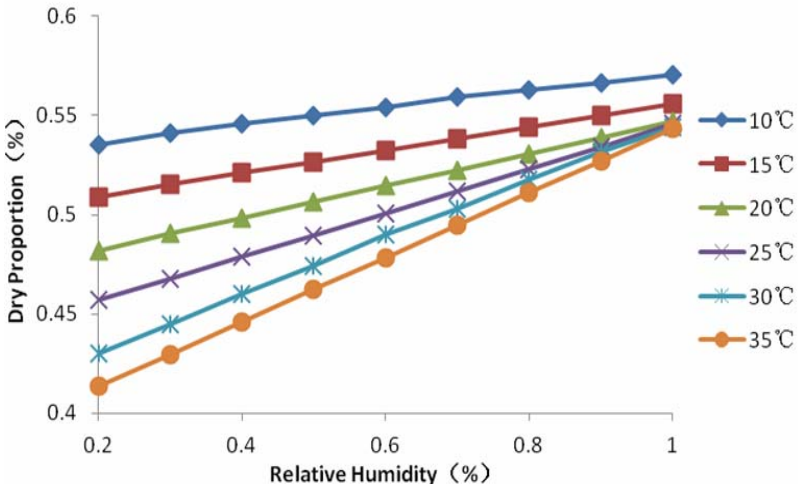

Figure 6. Relative humidity and ambient temperature influence on dry proportion-W\&D.

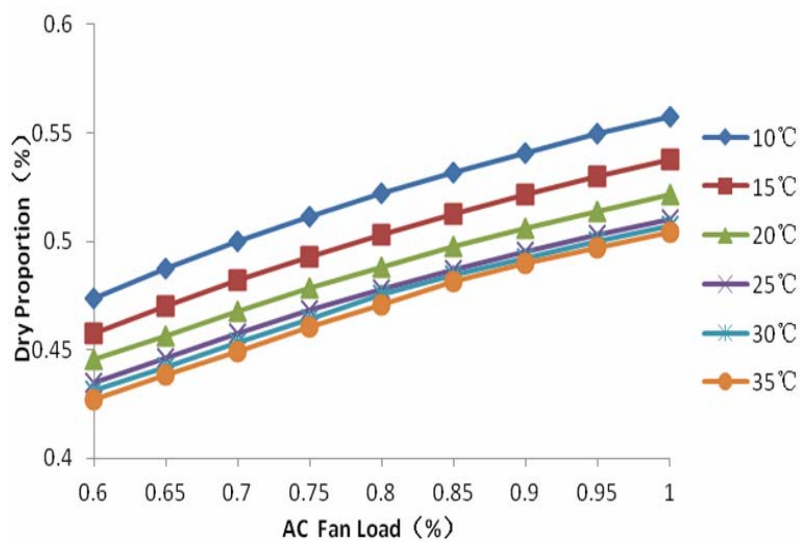

Figure 8. AC fan load and ambient temperature influence on dry proportion $-W \& D$.

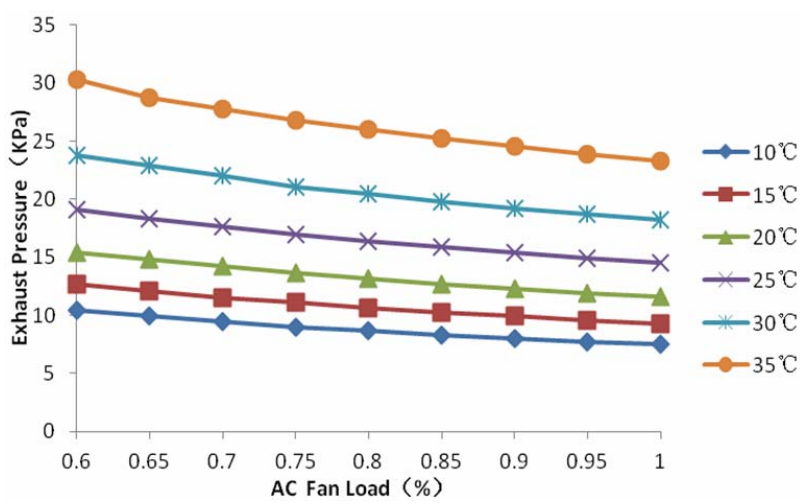

Figure 7. AC fan load and ambient temperature influence on exhaust pressure -W\&D.

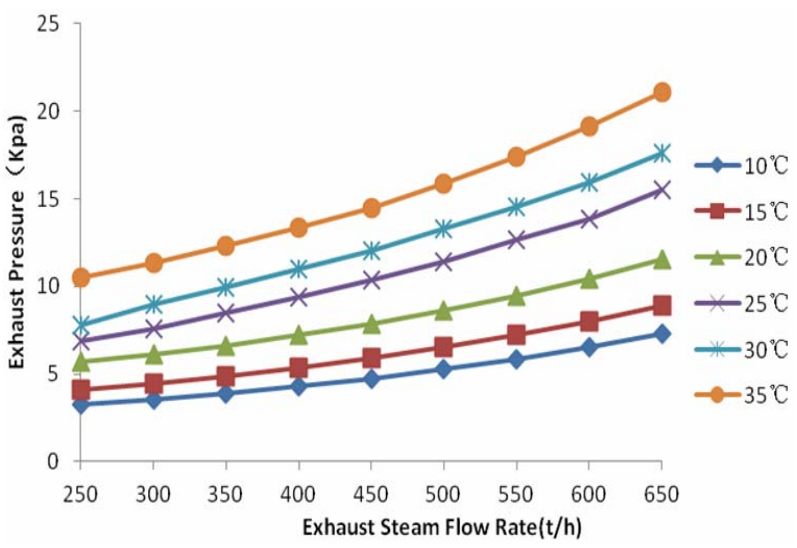

Figure 9. Exhaust steam flow rate and ambient temperature influence on exhaust pressure -W\&D. 
The influence of the exhaust steam flow rate on the cycle performance is shown in Figures 9-10. The exhaust pressure progressively increases with exhaust steam flow rate increases. The effect becomes more and more appreciable with increasing temperature. The way in which the exhaust steam is shared into the two condensers is shown in Figure 10, that a decreasing steam flow rate goes through the air cooling system as the ambient temperature increases from $10^{\circ} \mathrm{C}$ to $25^{\circ} \mathrm{C}$, but an increasing team flow rate goes through the air cooling system as the ambient temperature increases from $30^{\circ} \mathrm{C}$ to $35^{\circ} \mathrm{C}$. This behavious is consistent with the water cooling condenser has better performances in high temperature.

\subsection{Optimization of the Operation}

At the low temperature, the unit operate with direct air cooling system. Figure 11 report the results of the condensing system optimization procedure for the Dry configuration. The AC fan load which meet the power load at diffient ambient temperature is given in Figure 11. The AC fan load increses with rising ambint temperature. When the power load is $300 \mathrm{MW}$, it must open $\mathrm{D} \& \mathrm{~W}_{1}$ at $16^{\circ} \mathrm{C}$, and $\mathrm{D} \& \mathrm{~W}_{1}$ open at $24^{\circ} \mathrm{C}$ when power load is $225 \mathrm{MW}$, and $\mathrm{D} \& \mathrm{~W}_{1}$ open at $31^{\circ} \mathrm{C}$ when power load is $150 \mathrm{MW}$. When power load is lower than $120 \mathrm{MW}$, it's no need to open $\mathrm{D} \& \mathrm{~W}_{1}$.

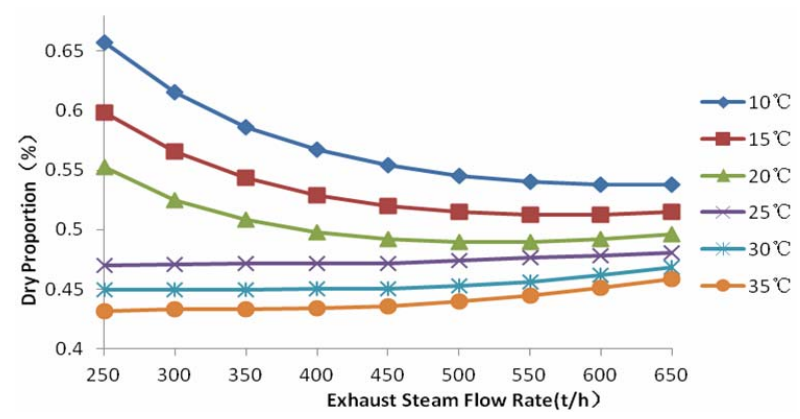

Figure 10. Exhaust steam flow rate and ambient temperature influence on dry proportion -W\&D.

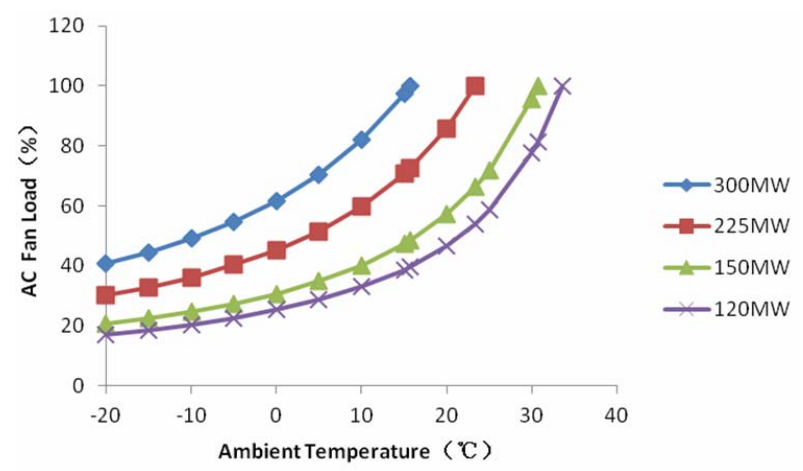

Figure 11. Power load and ambient temperature influence on AC fan load - Dry.

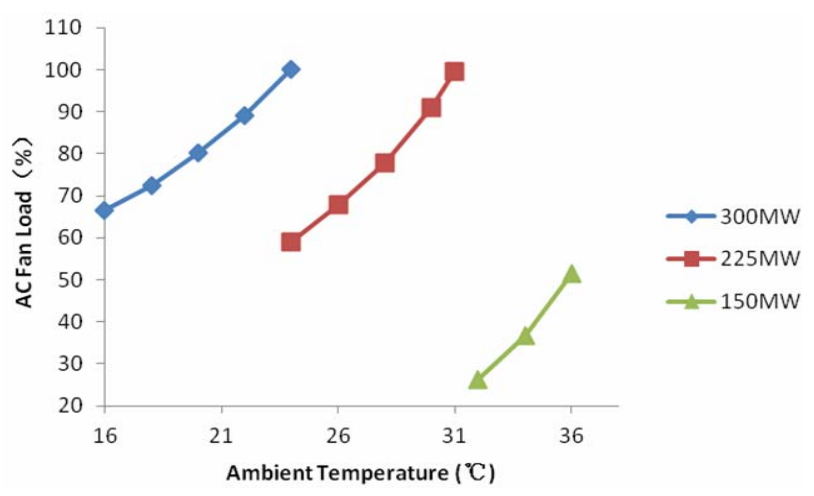

Figure 12. Power load and ambient temperature influence on AC fan load $-D \& W_{1}$.

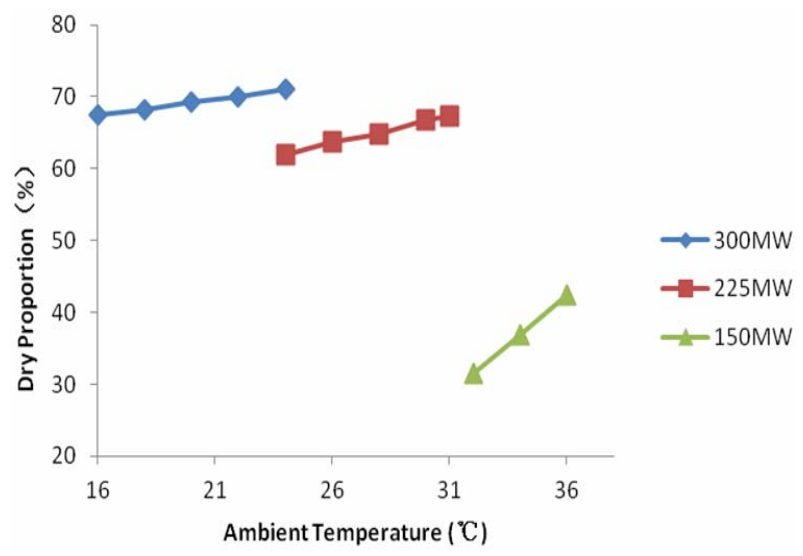

Figure 13. Power load and ambient temperature influence on dry propotion $-\mathrm{D} \& \mathrm{~W}_{1}$.

Figures 12-13 report the results of the condensing system optimization procedure for the $\mathrm{D} \& \mathrm{~W}_{1}$ configuration. The AC fan load which meet the power load at diffient ambient temperature is given in Figure 12. The AC fan load increses with rising ambint temperature. When the power load is $300 \mathrm{MW}$, it must open $\mathrm{D} \& \mathrm{~W}_{2}$ at $24^{\circ} \mathrm{C}$, and $\mathrm{D} \& \mathrm{~W}_{2}$ open at $31^{\circ} \mathrm{C}$ when power load is $225 \mathrm{MW}$. When power load is lower than $150 \mathrm{MW}$, it's no need to open ${\mathrm{D} \& \mathrm{w}_{2}}_{2}$.

Figures 14-15 report the results of the condensing system optimization procedure for the $\mathrm{D} \& \mathrm{~W}_{2}$ configuration. The AC fan load which meets the power load at different ambient temperature is given in Figure 14. The AC fan load increses with rising ambint temperature. When the power load is $225 \mathrm{MW}$, the exhaust pressure can keep $15 \mathrm{KPa}$ at any ambient temperature. But when the power load is $300 \mathrm{MW}$, the exhaust pressure can not keep $15 \mathrm{KPa}$ at ambient temperature is above $28^{\circ} \mathrm{C}$.

\section{Conclusions}

A detailed simulation of a wet and dry cooling system installed in a steam power plant was developed and some conclusions were made as follows: 


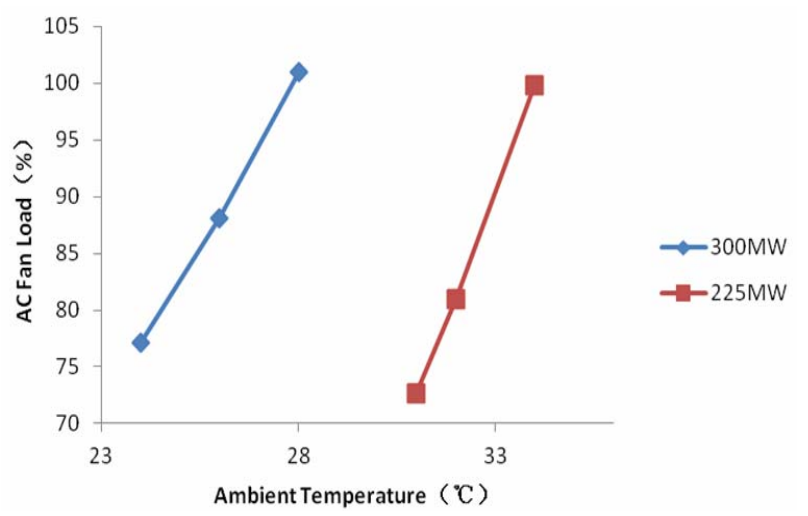

Figure 14. Power load and ambient temperature influence on AC fan load - D\& $W_{2}$.

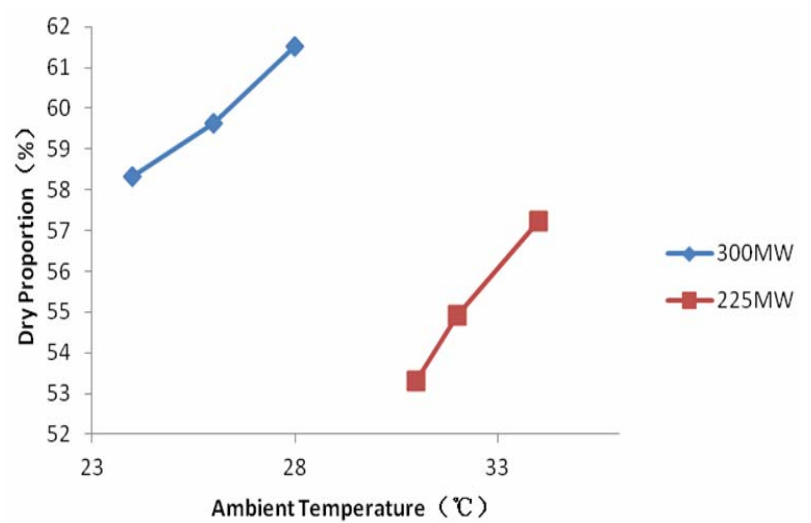

Figure 15. Power load and ambient temperature influence on dry propotion $-\mathrm{D} \& \mathrm{~W}_{2}$.

1) A parametric analysis was carried out in order to check the influence of ambient temperature, relative humidity, exhaust steam flow rate and air condenser fan load on the thermodynamic performances of a power plant with dry and cooling system.

2) In dry and wet cooling system, the exhaust pressure decreases with rising $\mathrm{AC}$ fan load, and increases with rising relative humidity and exhaust steam flow rate. The effect becomes more and more appreciable with increasing ambient temperature.

3) The heat load distribution of dry and wet cooling system in different operation situations was well developed. Steam flow rate to AC decreases with increasing ambient temperature, and increases with increasing air cooling condenser fan load and relative humidity, but when the exhaust steam flow rate increases, steam flow rate to $\mathrm{AC}$ may increase or may be decrease decided by the ambient temperature conditions.

4) The air cooled condenser resulted the best way to reject heat if the temperature is lower than $16^{\circ} \mathrm{C}, 24^{\circ} \mathrm{C}$, $31^{\circ} \mathrm{C}$, when the power load is $300 \mathrm{MW}, 225 \mathrm{MW}, 150$ MW. At higher ambient temperature, the condensation should exploit the cooling capacity of the tower as much as possible while discarding the remaining heat in the air condenser.

\section{REFERENCES}

[1] E. Ding, "Air Cooling Technology in Power Plant," M, Beijing: China Water Power Press, 1992 (in Chinese).

[2] J. A. Heyns, "Performance Characteristics of an Air-cooled Steam Condenser Incorporating a Hybrid (dry/wet) Dephlegmator," D, Depart of Mechanical Engineering, Uniwersity of Stellenbosch, 2008.

[3] P. Lindahl and R.W. Jameson, "Plume abatement and water conservation with wet/dry cooling towers," CTI Journal, Vol. 14, No. 2, 1993.

[4] D. G. KrÖger, "Air-cooled Heat Exchanger and Cooling Towers," USA: Penwell Corp, Tulsa, 2004.

[5] F. W. Yu and K. T. Chan, "Application of Direct Evaporative Coolers for Improving the Energy Efficiency of Air-cooling Chillers," Journal of solar Energy Engineering, Vol. 127, No. 3, 2005, pp. 430-433. doi:10.1115/1.1866144

[6] L. X. Zhou, et al, "Study on Variable Condition Features for 300 MW Direct Air-cooling Unit," J, Proceedings of the CSEE, Vol. 27, No. 17, 2007, pp. 78-82.

[7] S. P. Fisenko and A.I. Petruchik, "Toward to the Control System of Mechanical Draft Cooling Tower of Film Type,” Int J Heat Mass Transfer, 2005, Vol. 47, pp. 31-35. doi:10.1016/j.ijheatmasstransfer.2004.08.002

[8] J. Piskorowski, R. B. G. Beekett, "Condenser Perofrmanee Test and Baek-Pressure lmProvement," EPRI, CS.5729, Vol. 4, 1988, pp. 19-23.

[9] A. A. Brin, A. I. Petruchik, S. P. Fisenko, "Mathematical Modeling of Evaporative Cooling of Water in a Mechanical-draft Tower," Journal of Engineering Physics and Thermophysics, Vol. 75, No. 6, 2002, pp. 1332-1338. doi:10.1023/A:1022110809044 